\title{
Narrative, Temporality and the Modernist City
}

\begin{abstract}
The article explores the idea of temporality in relation to high-modernist literary representations of London. I claim that the modernist metropolis appears as a palimpsest whose memorialising function is upheld by techniques such as fragmentation, citation, myth, allegory, intertextual references or allusions, which question the stereotypical relationship between then and now, subject and site. It does so by deconstructing traditional temporal sequences and by foregrounding a subtle connection between past and present. Thus, the modernist city will be considered as a space of transformation in which the substantialness of space and subjective time translates the elusive meaning of contemporary history.

Keywords: the modernist city, London, palimpsest, subjective time, contemporary history
\end{abstract}

First used by Charles Baudelaire in his essay The Painter of Modern Life to describe "the ephemeral, the fugitive, the contingent" (Baudelaire, 1995, p. 13) quality of modern living, modernity is a concept that encapsulates the sense of rapid change that shapes human life in the industrialized urban centres of the latter half of the nineteenth century, where new technologies accelerate the speed of living and reshape the individual's perception of time and space. Subject to perpetual change and, implicitly, to the accumulation of various types of knowledge, the modern metropolis has been defined, in the words of Iain Chambers, as a "poignant narrative" understood as "the site of the ruins of previous orders in which diverse histories, memories and traces continually entwine and recombine in the construction of new horizons" (Chambers, 1990, p. 112). Acutely aware of progressivism paradoxically premised on a critique of contemporaneity, the modern city is a historical-cultural palimpsest deeply rooted in the conception of modernism as an art of disintegration which upholds the heterogeneity of the positions and manifestoes generated in response to the conditions of modern urban life by writers and artists working within and across a wide range of mediums. Written by recourse to mythical narratives that reconstruct the puzzle of cultural history, the modernist city captures "the

Ivana Dragoş, Centrul de excelență pentru studiul identității culturale, Universitatea din București, Strada Pitar Moş 7-13, sector 1, Bucharest, dragos.ivana@lls.unibuc.ro,

https://orcid.org/0000-0003-2992-1308 
panorama of futility and anarchy that is contemporary history" (Eliot, 1975, p. 178) and concurrently reveals significant underlying processes taking place in the psychological apprehension of the city. As an artificial, anomic and "Gesellschaft" environment literally and representationally constructed or produced according to modern(ist) interpretations of space and time, the city as palimpsest, or as a spatial and temporal metaphor translated by Mikhail Bakhtin as "chronotope" (Bakhtin, 1981), is built on the reminiscences of a Heideggerian type of past that "belongs irretrievably to an earlier time; it belonged to the events of that time; and in spite of that, it can still be present-at-hand now" (Heidegger, 1962, p. 378). Elaborating on Heidegger's idea, Lawrence Phillips cogently argues that "to produce meaning from the 'space' between the past and the 'present-at-hand' there is narrative" (Phillips, 2006, p. 4). According to this line of thought, I argue that high-modernist literary narratives of the city not only reveal, but also reconfigure past modes of representing the city. By high-modernist literature I understand the experimental works written by T.S. Eliot, James Joyce and Virginia Woolf in the 1920s, when "high" denoted an innovative and particularly elitist form of artistic creation and aesthetic judgement that was radically opposed to lowbrow culture. Such literature was engaged in reworking the concept of history, on the one hand, and in promoting both a sophisticated way of observing and experiencing the world and literature as high art, on the other. My task is to show that such narratives encode accounts of spatio-temporal simultaneism made possible by space engaged in an intense process of negotiation between images, histories and memories of the city encapsulated by the individual's subjective time theorized by Husserl in his 1928 Phenomenology of Internal Time-Consciousness. According to Lynch (1960), our perception of the city is "rather partial, fragmentary, mixed with other concerns. Nearly every sense is in operation, and the image is the composite of them all" (p. 2). The composite image whereby we make sense of our experience in the city is translated and codified through a narrative of consciousness, in which our mental experiences, acts and feelings have a specific duration, are re-enacted by memory and anticipated by consciousness. In this light, I claim that the modernist metropolis appears as a palimpsest whose memorialising function is prompted by techniques such as fragmentation, myth, allegory or intertextuality, which question the stereotypical relationship between past and present by annihilating traditional - be they linear, chronological or positivist - temporal sequences. Thus, the modernist city, most notably London, will be considered as a space of transformation in which the individual faces crisis "as a way of thinking about one's moment, and not inherent in the moment itself" (Kermode, 2000, p. 101) and seeks to decode the meaning of contemporary history.

In his analysis of London as a modernist city, Bradbury (1991) underlines its "English-language Modernist activity" (p. 172) which spawned a wide array of artistic experiments between 1890 and 1920. Though London exerted a great 
fascination on many outstanding artists at the dawn of the twentieth century, it was culturally inferior to Paris and, in the words of Bradbury (1991), an ill-reputed creative space which the social imaginary of the time depicted as

one of the dullest and most deadening of capital cities, with no real artistic community, no true centres, no coteries, no cafés, a metropolis given to commerce and an insular middle-class lifestyle either indifferent or implacably hostile to the new arts. Its image lives in Modernist writing itself. Its fascination and its repulsion, its status at the centre of vivid multiple impressions and as the city of dreadful night, have entered deeply into poetry and fiction, where a cluster of unforgettable associations surround it (p. 172).

However, such a besmirched social poetics of London does not prevent Bradbury from highlighting the fact that "the cosmopolitan and the nativist" (p. 174) formed an osmotic relationship which accounted for the rise of modernist aesthetics acutely concerned about forging the urban identity of London in the early twentieth century. Ford endorses this idea, noting that writers who portray London "ought to be alive to the glamour of old associations" and must take heed of "new haunts" that "are being formed for new people around whom will congregate new associations" which "will in their turn grow old, tender, romantic, glamorous enough" (Ford, 1995, p. 5). Ford makes straightforward reference to London, a city in which past and present coexist. Such a collage of temporal sequences is contingent upon fragments which bear no relation to the world as a whole, on the one hand, and to the allegedly comprehensive grand narratives "dissolved within the single element of receptive interiority" (Kwinter, 2001, p. 39).

London as a site of artistic experiments and social philistinism is a socio-cultural paradox Bradbury fails to resolve. Labelled as a kaleidoscope of contradictions and inconsistencies by Henry James, London "is a collection of many wholes, and of which of them is it most important to speak?" (James, 2011, p. 18). Apart from revealing epistemological uncertainties, James's statement suggests that the process of fictionalization substantially contributes to making sense of London as a polymorphous space. Thus, the textual London is subject to creation and shaping perception, it is "an enigmatic glow", "a vast graveyard of stilled hopes" (Ford, 1995, pp. 94, 95), which is highly indicative of the new qua modern urban consciousness. Though not entirely oblivious of the sediments of history, this profound and fragmentary consciousness brings forth what Henri Lefebvre calls "qualities of space" (Lefebvre, 2011, p. 230). They call for a twentieth-century type of sensibility of the city, a kind of sensibility comprised "of small little experiences, of little personal impressions, of small futile things that, seen in moments of stress and anguish, have significances so tremendous and meanings so poignant. A cloud - as it were of dust of men's lives" (Ford, 1995, p. 112). The new sensibility of the city is expressed by stories that are able to bridge physical and discursive spaces by inventing - in the etymological sense of in venire (to 
come into being) - a topography that unveils fragments of forgotten or neglected history. Employing Derridean and Deleuzian terminology, Wolfreys (2007) argues that the city's new sensibility becomes meaningful in writing understood as invention

in that technical sense of devising a form, a structure for memory. It taps time if you will, entering into the temporal core of place, of what has taken place in place and which imprints itself indelibly as the signature of place, awaiting invention by the subject who responds to the resonance of that location, who provides the inventive and corresponding locution to the location, in which give and take the singular locus of the city is neither simply in the subject or the particular place, but is instead discernible as the invenient becoming taking place, once more, between the subject and site [emphasis original] (p. 3).

Taken as "a structure for memory", the city is indelibly linked to the notion of circular time developed from Bergson's understanding of time as "durée", i.e. time as an ongoing process of "becoming", and foreshadowed by Nietzsche's eternal recurrence, Joyce's cyclical time and Eliot's fractured time in need of Christian redemption.

Virginia Woolf's "Portrait of a Londoner" is a case in point. "Portrait" is the sixth of a series of essays gathered together under the title The London Scene (1931), a collection initially published in 1981. It was discovered by Emma Cahill at the University of Sussex and reprinted by The Guardian in 2004. The essay foregrounds the image of London appropriated and encapsulated through gossip by Mrs Crowe, a Cockney lady who spent 60 years in the same London house. Plotless as it is, the essay juxtaposes the fashioning of the self with the perspective on the metropolis pulverized into a myriad of present-day singularities and perceptions that feed Mrs Crowe's imagination. Always eager to articulate the lived and living present offered by her guests every day, between 5 and 7 o'clock pm, under the form of easy yet polite conversation, Mrs Crowe acts as the embodiment of a private subject who fabricates her own version of London. Not only does she invent it, but she also establishes a perfect correspondence between "locution" and "location":

The truth was she did not want intimacy; she wanted conversation. Intimacy has a way of breeding silence, and silence she abhorred. There must be talk, and it must be general, and it must be about everything. It must not go too deep, and it must not be too clever, for if it went too far in either of these directions somebody was sure to feel out of it, and to sit balancing his tea cup, saying nothing (Woolf, 2004).

The "invenient" space acquires the status of a palimpsest of everyday opinions accumulated as observations dissected in the private drawing-room of a Victorian hostess, almost a legend of the city, who is informed of the public life of the 
metropolis - the macro-text read and interpreted by a motley community of Londoners:

Thus Mrs Crowe's drawing-room had little in common with the celebrated salons of the memoir writers. Clever people often came there - judges, doctors, members of parliament, writers, musicians, people who travelled, people who played polo, actors and complete nonentities [...] The talk that Mrs Crowe liked and inspired was a glorified version of village gossip. The village was London, and the gossip was about London life. But Mrs Crowe's great gift consisted in making the vast metropolis seem as small as a village with one church, one manor house and 25 cottages. She had first-hand information about every play, every picture show, every trial, every divorce case. She knew who was marrying, who was dying, who was in town and who was out (Woolf, 2004).

When Mrs Crow dies, Woolf confesses that "London will never be the same city again", for cityspace will display different qualities to be recorded by different psyches. Her death symbolizes the death of the London of her time that she synecdochically embodies and it is precisely this past that future generations of Londoners might feel estranged from, since London's history, the metropolis reduced to "a small village", is only the history of a small portion of the city constructed through discourse.

If the city is "a temporal container" (Weinstein, 2014, p. 139), then one may argue that the modernist city propels memory into action so as to allow for a more comprehensive relationship between subject and space. The liaison between memory/images and discourse taken as narrative/story or history becomes effective when dealing with the description of the lived experience of the city in fragmentary form. In the words of Weinstein (2006, p. 17), "living your life is not a guided tour. Modernist literature isn't, either". He is right in saying that "the kinetic renditions of the modernist city" shatters "our familiar assumptions about subject/setting, about inside/outside, about now/then and here/there" (Weinstein, 2014, p. 139). Eliot's praise of Joyce's mythopoeic method used in Ulysses actually becomes his own project in The Waste Land, where escapism from "the panorama of futility and anarchy that is contemporary history" is achieved through art. The disconnected stories, fragments, quotations, allusions, intertextual references and footnotes disconcert the reader, who is puzzled by the literary and cultural traces at work throughout the poem. In this cultural cryptogram time is represented as spatial plots in the flow of consciousness: the discovery of unexpected transitions and suppositions, images rather than statements, or images as statements in the vein of Ezra Pound's imagistic poems. In doing so, Eliot, like other high modernists, elevates fragmentariness to an aesthetic level and modus operandi meant to convey the wavering experience of the city by bringing the past into the present in a simultaneous manner. According to Wolfreys, London is "the invenient becoming taking place" the moment the barrenness of the city prevails upon the poet's consciousness as well. By having recourse to the myth of the Fisher King, Eliot depicts the city as an apocalyptic image 
of destruction, as an entity affected by a de-realized ontology, as spatial otherness indicating both an existential crisis and a crisis in faith. As a mosaic of ruins, or "as a poem of modern ruin-gazing" (Morrison, 2015, p. 29), The Waste Land depicts the destructive process of modern urbanization grasped in a subjective manner. "The fragments I have shored against my ruins" (Eliot, 1969, p. 430) articulate the rhetorical strategy of the poem and, concurrently, the interdependence between the past and the present perceived not only as physical space, but also as subjective temporality. The fragments that populate the poem are on a par with the shattered buildings of urban modernity. As Morrison (2015) suggests, there is an excess of meaning in the urban ruins which is apt "to invoke multiple and fragmented pasts while simultaneously gesturing to indeterminate possible futures" (p. 31). Invested with a temporal dimension, ruins point to an apprehensive subjectivity tightly related to the decaying present, i.e., London's destruction. Much in the vein of Woolf, Eliot composes "in-betweens of time, text, and being" (McIntire, 2008, p. 211) with the help of cultural patches embedded in the past and the present, or imaginatively projected into a blurred future. Eliot's palimpsestic city is invented within the historical situatedness of modernity and at the same time reinvented through fragments of everyday life Terry Eagleton labels as "a self-transformative organism extended in time and space, constantly reorganised by [the idioculture of] the present" (Eagleton, 1978, p. 147). Similarly, Ulysses stages individual stories that reveal Dublin as an ultimately incoherent and chaotic metropolis that needs to be decrypted by a "flâneur-reader" like Leopold Bloom, who is part and parcel of the polyphony of urban life and its "traffic (human, neural, not just vehicular) [emphasis original]" (Weinstein, 2014, p. 142). Nevertheless, Joyce's Dublin, much like Virginia Woolf's London in Mrs Dalloway, is grasped and experienced through an irregular shifting in time-consciousness, one of the prerequisites of modernist plotless writing.

An urban background in which history and life are interwoven, Virginia Woolf's London is the setting not only of her collection of essays titled The London Scene, but also of a few stories and novels, of which Mrs Dalloway is a telling example. Woolf's fascination with the vibrant though evasive metropolis may be inferred from her thoughts jotted down in her diary: "One of these days, I will write about London and how it takes up the private life and carries on, without any effort" (Woolf, 1978, p. 301). Transformed into a space which constructs the selves of various characters, London plays a crucial role in shaping consciousness by letting ourselves get out of our selves and become one with the "outside world" epitomised by the hustle and bustle of the city. In her essay "Street Haunting: A London Adventure", she summarises this point as follows: 
minds of others. One could become a washer-woman, a publican, a street singer (Woolf, 1966, p. 165).

Erasing class boundaries, Woolf's statement creates an environment that is propitious for a modernist urban flâneuse who, in stark contrast to Mrs Crowe, contributes to reconfiguring cityscape and the experience of the public space at the dawn of the twentieth century, on the one hand, and to how London shapes memory and social behaviour, on the other.

Mrs Dalloway portrays London as a paragon of lively modern life and dominating presence of space attuned to the fluctuations between external $/$ physical and internal/subjective time. Woolf regards consciousness and urban environment as "mutually interactive and expressive" (Parsons, 2000, p. 69), in that London is the locus and nexus of many stories and histories of the city, which become tightly connected with characters that must have a traceable past. "I dig out beautiful caves behind my characters" (Olivier \& McNeillie, 1978, p. 272) represents Woolf's recipe for designing Mrs Dalloway as "a vast site of excavation, yielding itself up to the novelist as archaeologist whose task it is to unearth or bring to 'daylight' the subterranean links between individual consciousnesses" (Tromanhauser, 2004, p. 36). The novelist as "archaeologist" goes hand in hand with the city as a palimpsest of histories and biographies that are brought to life under the guise of modernist epiphanies experienced in the most commonplace circumstances of ordinary life. Here is a long-lasting moment of exhilaration experienced by Clarrisa when she gets immersed in the animated city:

In people's eyes, in the sing, tramp and trudge; in the bellow and uproar; the carriages, motor cars, omnibuses, vans, sandwich men shuffling and swinging; brass bands; barrel organs; in the triumph and the jingle and the strange high singing of some aeroplane overhead was what she loved; life; London; this moment of June (Woolf, 1990, p. 4).

The image of London condensed into "a moment" functions as a repository of stories, histories and biographies gradually uncovered against the backdrop of Big Ben, the epitome of external time that interrupts the internal flow of thoughts compressed during a single day of June. Woolf's "encounter-theme of city texts and city life" (Weinstein, 2014, p. 144) sets the frame for the party, distinguishing between Clarissa's exuberant view of London life and Septimus's grim picture of the city: "[...] and once a maimed file of lunatics being exercised or displayed for the diversion of the populace (who laughed aloud), ambled and nodded and grinned past him ... each half apologetically, yet triumphantly, inflicting his helpless woe" (Woolf, 1990, p. 90). Septimus stands solid proof that London is constructed through the subjectivities of its observers and that the city throws us into the anonymous crowd. According to de Certeau, the subjective and the social are mutually interactive in a space metaphorically constructed by 
those who view it as unstable, kinetic, "produced by the operations that orient it, situate it, temporalize it" (de Certeau, 1988, p. 117). Instability accounts for a limited view of space and time, which calls for the need to organize life in accordance with a coherent matrix made up of fragments of truth revealed through intuition.

Such representations of London, or of Joyce's Dublin, were perceived by highmodernist writers as a centre of post-war crisis, stasis, and paralysis understood as "a way of thinking of one's moment", to quote Kermode again, which is aesthetically translated as a living moment in one's consciousness. Always predicated on the writer's or artist's imagination, the city, notwithstanding its palimpsestic nature, is permanently fictionalized and morphed into a pivotal figure of Modernist literature. Written, invented or appropriated as a landscape of the mind, highmodernist London discloses a network of fragments, traces of, and intersections with, the past that further engender an endless series of Londons, each one being "the crystallization or actualization of the city's countless singularities, its countless moments of taking place, of becoming" (Wolfreys, 2007, p. 3). As such, writing the city in a modernist manner has been an invention of a plethora of meanings of "the panorama of futility and anarchy that is contemporary history" and, more significantly, an "invenient becoming", according to Wolfreys, which looks backward and forward, (re)appropriating the past under the guise of ruins and fragments that turn London into a palimpsest which blends forgetting, remembering and the acute awareness of the present.

\section{References}

Bakhtin, M. (1981). The Dialogical Imagination: Four Essays (C. Emerson \& M. Holquist, Trans.). Austin: University of Texas Press.

Baudelaire, C. (1995). The Painter of Modern Life and Other Essays (J. Mayne, Trans.). London: Phaidon Press.

Bradbury, M. (1991). London 1890-1920. In M. Bradbury, \& J. McFarlane (Eds.) Modernism: A Guide to European Literature 1890-1930 (pp. 172-190). Harmondsworth: Penguin.

Chambers, I. (1990). Border Dialogues: Journeys in Postmodernity. London, New York: Routledge.

De Certeau, M. (1988). The Practice of Everyday Life (S. Rendall, Trans.). Berkeley: University of California Press.

Eagleton, T. (1978). Criticism and Ideology: A Study in Marxist Literary Theory. London: Verso.

Eliot, T. S. (1969). The Complete Poems and Plays. London: Faber and Faber.

Eliot, T. S. (1975). Ulysses, Panorama, and Myth. In F. Kermode (Ed.), Selected Prose of T. S. Eliot (pp. 175-178). New York: Harcourt.

Ford, M. F. (1995). The Soul of London: A Survey of a Modern City. London: Dent.

Heidegger, M. (1962). Being and Time (E. Robinson \& J. Macquarrie, Trans.). Oxford: Blackwell. James, H. (2011). English Hours: A Portrait of a Country. London: Tauris Parke Paperbacks.

Kermode, F. (2000). The Sense of an Ending. Oxford: Oxford University Press.

Kwinter, S. (2001). Architectures of Time: Toward a Theory of the Event in Modernist Culture. Cambridge, Massachusetts: MIT Press.

Lefebvre, H. (2011). The Production of Space (D. Nicholson-Smith, Trans.). Oxford: Blackwell. 
Lynch, K. (1960). The Image of the City. Cambridge, Massachusetts: MIT Press.

McIntire, G. (2008). Modernism, Memory, and Desire: T. S. Eliot and Virginia Woolf. Cambridge: Cambridge University Press.

Morrison, S. (2015). Geographies of Space: Mapping and Reading the Cityscape. In G. McIntire (Ed.), The Cambridge Companion to The Waste Land (pp. 24-38). Cambridge: Cambridge University Press. DOI: https://doi.org/10.1017/CBO9781107279612.003.

Olivier, A. B., \& McNeillie A. (Eds.). (1978). The Diary of Virginia Woolf: Vol. 2. New York: Harcourt.

Parsons, D. (2000). Streetwalking the Metropolis: Women, the City, and Modernity. Oxford: Oxford University Press.

Phillips, L. (2006). London Narratives: Post-war Fiction and the City. London and New York: Continuum.

Tromanhauser, V. (2004). Virginia Woolf's London and the Archaeology of Character. In L. Phillips (Ed.), The Swarming Streets: Twentieth-Century Literary Representations of London (pp. 3343). Amsterdam, New York: Rodopi.

Weinstein, A. (2006). Recovering Your Story: Proust, Joyce, Woolf, Faulkner, Morrison. New York: Random House.

Weinstein, A. (2014). Fragment and Form in the City of Modernism. In K. R. McNamara (Ed.), The Cambridge Companion to the City in Literature (pp. 138-152). Cambridge: Cambridge University Press.

Wolfreys, J. (2007). Writing London: Inventions of the City: Vol. 3. London: Palgrave Macmillan.

Woolf, V. (1966). Street Haunting: A London Adventure. In L. Woolf(Ed.), The Collected Essays of Virginia Woolf, Vol. 4 (pp. 155-167). London: Hogarth Press.

Woolf, V. (1990). Mrs Dalloway. San Diego: Harcourt.

Woolf, V. (2004, August 11). Portrait of a Londoner. The Guardian. Retrieved February 25, 2020, from https://www.theguardian.com/books/2004/aug/11/virginiawoolf. 